\title{
DINAMIKA KERAGAAN KEMISKINAN DI DESA PATANAS DAN UPAYA MENGATASINYA
}

\author{
Valeriana Darwis \\ Peneliti di Pusat Sosial Ekonomi dan Kebijakan Pertanian \\ E-mail: valerianadarwis@yahoo.co.id
}

\begin{abstract}
Poverty reduction is a priority development agenda and a lot of programs or policies that have been implemented by the government. One of the pockets of poverty are diperdesaan where people work in the agricultural sector. In locations irrigated rice agro-ecosystem study the performance of rice-based poverty in 2007 and 2010 experienced a negative growth, it is seen from: (i) reduced employment and increased unemployment, (ii) a source of income from agriculture generally, but she became a source of income in non-agriculture, (iii) land ownership between 0.25 to 1 ha and reverse the decline of arable land rent is increasing, (iv) expenditure on food increased primarily to meet the needs of carbohydrates and animal sources. The dynamics of the most positive efforts made respondents in addressing the problem of food by way of debt, overcoming difficulties by reducing the amount of clothing purchases, overcoming difficulties fulfilling its way into participants health insurance for the poor, addressing educational problems by borrowing money or do not attend school.
\end{abstract}

Keywords : Dynamics and efforts to overcome poverty

\begin{abstract}
Abstrak : Pengentasan kemiskinan menjadi prioritas agenda pembangunan dan banyak program atau kebijakan yang sudah dilaksanakan oleh pemerintah. Salah satu kantong kemiskinan berada diperdesaan yang masyarakatnya bekerja di sektor pertanian. Di lokasi penelitian agroekosistem sawah irigasi berbasis padi keragaan kemiskinan tahun 2007 dan 2010 mengalami pertumbuhan yang negatif, hal ini terlihat dari : (i) kesempatan kerja berkurang dan pengangguran bertambah, (ii) sumber pendapatan umumnya dari pertanian, tetapi sumber pendapatan justru bertambah di non pertanian, (iii) kepemilikan lahan antara 0,25 - 1 ha mengalami penurunan dan sebaliknya yang menyewa lahan garapan semakin bertambah, (iv) pengeluaran untuk kebutuhan pangan bertambah terutama untuk memenuhi kebutuhan karbohidrat dan sumber hewani. Dinamika upaya postif yang paling dilakukan responden dalam mengatasi masalah pangan dengan cara berhutang, mengatasi kesulitan sandang dengan cara mengurangi jumlah pembelian, mengatasi kesulitan memenuhi kesehatan dengan cara menjadi peserta askeskin, mengatasi masalah pendidikan cara meminjam uang atau tidak melanjutkan sekolah.
\end{abstract}

Kata Kunci : Dinamika dan upaya mengatasi kemiskinan

\section{PENDAHULUAN}

Menurut data BPS tahun 2014 jumlah penduduk miskin di Indonesia tahun 2013 mencapai 28.07 juta orang atau 11,37 persen dari jumlah penduduk. Penyebab utama kemiskinan $\quad(73,52 \%)$ karena tidak terpenuhinya kecukupan makanan seperti : beras, telur ayam ras, mie instan, gula pasir, tempe dan bawang merah. Sebaliknya faktor non makanan yang mempengaruhi garis kemiskinan antara lain : biaya perumahan, listrik, pendidikan dan bensin.

Banyak program yang sudah dilaksanakan pemerintah dalam mengentaskan kemiskinan, terutama dalam upaya menjadikan 
penduduk miskin di Indonesia menjadi 8-10 persen seperti yang tertuang dalam salah satu tujuan MDGs. Keseriusan ini juga tertuang dalam kebijakan pemerintah yang menyiapkan anggaran 28 triliun pada tahun 2004 menjadi 99,2 trilun pada tahun 2012. Dalam kurun waktu tersebut jumlah penduduk yang keluar dari predikat miskin sebanyak 7 juta jiwa atau berkurang dari 36,1 juta jiwa pada tahun 2004 menjadi 29,13 juta pada tahun 2012 (Made. B. 2013).

Upaya mengentaskan kemiskinan bukan menjadi tanggungjawab pemerintah saja melainkan tanggungjawab umat manusia termasuk masyarakat miskin itu sendiri. Hal ini sesuai dengan pidato Mandela dalam pertemuan dengan para menteri keuangan Group of Seven (G7) Febuari 2005 “ Seperti perbudakan dan Apartheid, kemiskinan tidak alamiah. Kemiskinan adalah perbuatan manusia dan dapat diatasi dan dientaskan melalui berbagai tindakan umat manusia." (Suara Pembaruan, 2013). Menurut Raiffeisen dalam Suroto (2014) akar kemiskinan itu adalah ketergantungan pada tiga hal, yaitu : ketergantungan pada sedekah, politik dan rentenir. Kemiskinan tidak bisa dientaskan dengan cara pengharapan dari derma (karitatif) saja tetapi perlu juga usaha untuk menolong diri sendiri, mengelola sendiri dan tanggungjawab sendiri.

Penduduk miskin paling banyak berdomisili di pedesaan, berdasarkan data BPS tahun 2013 penduduk miskin di pedesaan sebanyak 17,74 juta jiwa sementara penduduk miskin yang berada di perkotaan sebanyak 10,33 juta jiwa. Ada beberapa penyebab kemiskinan lebih banyak di pedesaan diantaranya adalah : (i) terbatasnya aset produktif seperti lahan dan modal, (ii) kualitas sumberdaya manusia sebagian besar sangat rendah (Kasryno dan Suryana. 1992). Sementara menurut Mason (1996) dan Iksan (1998) ada beberapa determinan kemiskinan di pedesaan, yaitu (i) human capital endowment yang belum memadai, sehingga menyulitkan proses transformasi tenaga kerja antar sektor. (ii) kuantitas dan kualitas infrastruktur yang belum memadai, (iii) distribusi kepemilikan lahan yang semakin kecil, (iv) kebijakan pemerintah yang terlalu bias kepada beras, sehingga mendistorsi komoditi lainnya.
Menurut Harniati (2007), fenomena kemiskinan perdesaan dan pertanian di Indonesia menunjukan adanya kaitan antara faktor spasial dan sektor usaha mayoritas penduduknya. Terdapat hubungan erat antara kerentanan penduduk terhadap kemiskinan dengan ekosistem dimana ia tinggal atau dengan kata lain tingkat kemiskinan berbeda antar ekosistem. Tingkat kemiskinan penduduk di agroekosistem dataran tinggi, lahan basah dan lahan kering, pantai/pesisir dibawah angka kemiskinan nasional. Namun jumlah rumah tangga miskin di lahan kering dan di dataran tinggi jauh lebih besar dari pada di lahan basah dan pesisir. Oleh karena itu, penanggulangan kemiskinan tidak bisa lagi menggunakan suatu pola umum (one fits for all) tetapi perlu mengembangkan berbagai model yang sesuai spesifik karakteristik kemiskinan di berbagai agroekosistem.

Masyarakat pedesaan pada umumnya bekerja di sektor pertanian dan pendapatan disektor pertanian belum bisa memenuhi kebutuhan petani. Hal ini direpresentasikan dari hasil Sensus Pertanian 2013 (ST 2013) dimana rata-rata pendapatan rumah tangga pertanian dari usaha pertanian mencapai Rp 12,41 juta pertahun atau Rp 1,03 juta perbulan. Angka ini masih dibawah Upah Minimum Propinsi terendah di Indonesia yaitu Provinsi Nusa Tenggara Timur sebesar Rp 1,15 juta perbulan.

Dengan uraian diatas tulisan ini bertujuan melihat kemiskinan dan upaya mengentaskan kemiskinan di petani yang menjadi responden pada penelitian Patanas. Agar terlihat dinamikanya maka data yang dipergunakan adalah data hasil penelitian Patanas pada tahun 2007 dan 2010.

\section{METODE PENELITIAN}

Agar terlihat dinamikanya, maka penelitian Patanas (Panel Petani Nasional) dilakukan secara berkesinambungan di tiga agroekosistem yang berbeda dalam dua titik waktu. Tahun 2007 dan 2010 survey rumahtangga dilakukan di agroekosistem sawah irigasi berbasis padi ; tahun 2008 dan 2011 survey rumahtangga dilakukan di agroekosistem lahan kering berbasis sayuran dan palawija ; tahun 2009 dan 2012 survey rumahtangga dilakukan di agroekosistem lahan kering berbasis komoditas 
perkebunan. Untuk tulisan kali ini hanya melihat dinamika di lokasi penelitian Patanas pada tahun 2007 dan 2010 dengan lokasi penelitian di Provinsi Jawa Barat, Jawa Timur, Sumatera Utara dan Sulawesi Selatan (Tabel 1).

Responden yang dipilih berdasarkan rumahtangga blok Sensus Pertanian 2003. Blok sensus yang terpilih merupakan daerah sentra komoditas yang dianalisis yang memiliki sumberdaya lahan dan jumlah rumahtangga terbanyak. Dari daftar rumahtangga blok sensus yang terpilih, dipilih secara acak 25 rumahtangga pemilik penggarap dan penggarap usahatani padi (Irawan, $d k k$. 2007). Rumahtangga yang terpilih tersebut kemudian diwawancarai dengan mempergunakan pertanyaan terstruktur (kuesioner). Data primer yang terkumpul kemudian dianalisa dengan metode analisis deskriptif dan ditampilkan dalam bentuk tabel. Untuk melihat dinamika rumahtangga responden dipergunakan analisa margin dua titik waktu.

\section{HASIL DAN PEMBAHASAN}

\section{KERAGAAN KEMISKINAN}

\section{Angkatan Kerja dan Sumber Pendapatan}

Menurut BPS yang dimaksud dengan angkatan kerja adalah penduduk berumur 15 tahun keatas yang selama seminggu sebelum pencacahan berstatus bekerja atau mempunyai pekerjaan tetapi sementara tidak bekerja dan mereka tidak bekerja tetapi sedang mencari pekerjaan. Sedangkan defenisi kesempatan kerja adalah rasio jumlah angkatan kerja yang bekerja dengan jumlah penduduk, sebaliknya rasio jumlah angkatan kerja yang tidak bekerja dengan jumlah penduduk disebut dengan tingkat pengangguran.
Berdasarkan defenisi BPS angkatan kerja di lokasi desa Patanas mengalami dinamika yang cenderung negatif untuk kesempatan kerja dan sebaliknya positif untuk pengangguran (Tabel 2). Provinsi Jawa Barat di Desa Tugu tahun 2010 penganggurannya naik 12.1 persen dibanding tahun 2007. Sebaliknya di Desa Simpar tingkat pengangguran mengalami penurunan 0,8 persen. Desa - desa yang ada di Provinsi Jawa Timur, Sumatera Utara dan Sulawesi Selatan seluruhnya mengalami peningkatan pengangguran dengan persentase paling tinggi terjadi di Desa Salu Jambu (29.7\%) dan paling rendah di Desa Padomasan (0.8\%).

Salah satu penyebab dari kemiskinan adalah penganguran dan tingkat penganguran di sektor pertanian berkisar 17-25 persen dari total angkatan kerja (Kustiari, et. al. 2008) dan 24,72 persen merupakan tenaga kerja setengah menganggur (Rusastra, et. al. 2005). Pada dasarnya masalah kesempatan kerja erat kaitannya dengan masalah rendahnya kesempatan kerja dan masalah kemiskinan (Mubyarto, 1976). Dengan bertambahnya tenaga kerja produktif yang menganggur, merepresentasikan telah terjadi peningkatan kemiskinan di keluarga responden desa Patanas.

Menurut Darwis. V dan A.R. Nurmanaf (2001) ada empat ciri yang melekat pada keluarga miskin, yaitu : banyaknya jumlah tanggungan anggota rumah tangga, berpendidikan rendah, kepemilikan asset yang rendah dan pekerjaan utama di sektor pertanian Hal yang sama juga terlihat di desa Patanas dimana seluruh angkatan kerja mengantungkan sumber pendapatan utama berasal dari sektor pertanian (Tabel 3). Sebaliknya berdasarkan

Tabel 1. Lokasi Penelitian Patanas Menurut Provinsi, Kabupaten, Kecamatan dan Desa

\begin{tabular}{lllll}
\hline No & Propinsi & Kabupaten & Kecamatan & Desa \\
\hline 1. & Jabar & Indramayu & Lelea & Tugu \\
& & Subang & Cipunegara & Simpar \\
2. & \multirow{2}{*}{ Jatim } & Banyuwangi & Genteng & Kaligondo \\
& & Lamongan & Sekaran & Sungegeneng \\
& & Jember & Jombang & Padomasan \\
3. & Sumut & Batu Bara & Lima Puluh & Kwala Gunung \\
& & Serdang Bedagai & Perbaungan & Lidah Tanah \\
4. & Sulsel & Luwu & Lamasi & Salujambu \\
& & Sidrap & Watang Pulu & Carawali \\
\hline
\end{tabular}

Sumber : Irawan, B et.al. (2007) 
Valeriana Darwis :Dinamika keragaan kemiskinan di desa patanas .....

Tabel 2. Angkatan Kerja, Kesempatan Kerja dan Pengganguran

\begin{tabular}{|c|c|c|c|c|c|c|c|c|c|}
\hline \multirow[t]{2}{*}{ Provinsi } & \multicolumn{3}{|c|}{$2007(\%)$} & \multicolumn{3}{|c|}{$2010(\%)$} & \multicolumn{3}{|c|}{ Dinamika (\%) } \\
\hline & $\mathrm{AK}$ & KK & $\mathrm{P}$ & $\mathrm{AK}$ & KK & $P$ & $\mathrm{AK}$ & KK & $\mathrm{P}$ \\
\hline Jawa Barat & & & & & & & & & \\
\hline Tugu & 74.5 & 64.0 & 10.4 & 77.5 & 61.6 & 22.5 & 3.0 & -2.4 & 12.1 \\
\hline Simpar & 80.8 & 56.4 & 24.4 & 76.4 & 48.6 & 23.6 & -4.4 & -7.8 & -0.8 \\
\hline Kaligondo & 80.7 & 61.5 & 7.1 & 73.8 & 51.7 & 26.2 & -6.9 & -9.8 & 19.1 \\
\hline Sungegeneng & 80.1 & 58.7 & 5.6 & 69.8 & 47.3 & 24.7 & -10.3 & -11.4 & 19.1 \\
\hline Padomasan & 77.8 & 62.0 & 16.1 & 70.9 & 50.0 & 16.9 & -6.9 & -12.0 & 0.8 \\
\hline Kwala Gunung & 70.9 & 48.9 & 24.4 & 59.4 & 44.9 & 40.6 & -11.5 & -4.0 & 16.2 \\
\hline Lidah Tanah & 73.3 & 57.5 & 13.4 & 63.7 & 45.6 & 35.7 & -9.6 & -11.9 & 22.3 \\
\hline Sulawesi Sel. & & & & & & & & & 297 \\
\hline $\begin{array}{l}\text { Salu Jambu } \\
\text { Carawali }\end{array}$ & $\begin{array}{l}01.5 \\
72.4\end{array}$ & $\begin{array}{l}4.0 \\
53.9\end{array}$ & $\begin{array}{l}12.0 \\
341\end{array}$ & 71.4 & 35.1 & 351 & $\begin{array}{l}-3.0 \\
-10\end{array}$ & $\begin{array}{l}-25.5 \\
-18.8\end{array}$ & $\begin{array}{r}29.1 \\
10\end{array}$ \\
\hline
\end{tabular}

Ket : $\mathrm{AK}=$ angkatan kerja $; \mathrm{KK}=$ kesempatan kerja ; $\mathrm{P}=$ pengangguran

Sumber : Irawan, B et.al. (2007) : Susilowati, H.S et.al. (2010)

Tabel 3. Angkatan Kerja Yang Bekerja Menurut Sumber Pendapatan

\begin{tabular}{lrrrrrr}
\hline \multirow{2}{*}{ Provinsi } & \multicolumn{2}{c}{$2007(\%)$} & \multicolumn{2}{c}{$2010(\%)$} & \multicolumn{2}{c}{ Dinamika (\%) } \\
\cline { 2 - 7 } & Pertanian & $\begin{array}{c}\text { Non } \\
\text { Pertanian }\end{array}$ & Pertanian & $\begin{array}{c}\text { Non } \\
\text { Pertanian }\end{array}$ & Pertanian & $\begin{array}{c}\text { Non } \\
\text { Pertanian }\end{array}$ \\
\hline Jawa Barat & & & & & & \\
Tugu & 87.2 & 12.8 & 71.9 & 28.1 & -15.3 & 15.3 \\
Simpar & 72.8 & 27.2 & 67.2 & 32.8 & -5.6 & 5.6 \\
Jawa Timur & & & & & & \\
Kaligondo & 78.0 & 22.0 & 73.9 & 26.1 & -4.1 & 4.1 \\
Sungegeneng & 77.3 & 22.7 & 71.0 & 29.0 & -6.3 & 6.3 \\
$\begin{array}{l}\text { Padomasan } \\
\text { Sumatera_Utara }\end{array}$ & 81.1 & 18.9 & 76.7 & 23.3 & -4.4 & 4.4 \\
Kwala Gunung & 81.0 & 19.0 & 66.0 & 34.0 & -15.0 & 15 \\
Lidah Tanah & 74.5 & 25.5 & 60.3 & 39.7 & -14.2 & 14.2 \\
Sulawesi Selatan & & & & & & \\
Salu Jambu & 89.1 & 10.9 & 83.6 & 16.4 & -5.5 & 5.5 \\
Carawali & 71.1 & 28.9 & 75.7 & 24.3 & 4.6 & -4.6 \\
\hline
\end{tabular}

Sumber : Irawan, B et.al. (2007) : Susilowati, H.S et.al. (2010)

dinamika sumber pendapatan meskipun masih dominan bekerja di sektor pertanian, tetapi dalam kurun waktu tiga tahun hanya satu desa saja yang bertambah persentase responden yang mengantungkan sumber pendapatan utamanya dari sektor pertanian, yaitu Desa Carawali. Sebalik desa yang lain respondennya mengalami peningkatan pendapatan dari usaha atau bekerja di sektor non pertanian.

Penurunan kesempatan kerja di sektor pertanian bisa disebabkan oleh inovasi adopsi teknologi budidaya yang terus berkembang dan terjadinya diversifikasi lapangan pekerjaan sejalan dengan proses pembangunan di pedesaan. Adapun lapangan pekerjaan yang ada di luar sektor pertanian seperti menjadi pegawai negeri sipil, perdagangan khususnya hasil bumi, jasa angkutan seperti angkutan desa dan ojek, penyerapan tenaga kasar yang tidak butuh pendidikan formal seperti menjadi buruh bangunan.

Beberapa permasalahan lainnya sehingga berkurangnya angkatan kerja di sektor pertanian antara lain : (i) kesempatan kerja di luar sektor pertanian yang mulai terbatas, (ii) kesempatan kerja dan bekerja di pertanian belum mengarah pada agroindustri dan masih berorientasi peningkatan penduduk, (iii) 
ketersediaan tenaga kerja di luar sektor pertanian terbatas, (iv) rendahnya sarana dan prasarana komunikasi sehingga pola migrasi dan mobilitas sangat rendah dan (v) keterbatasan infromasi pasar tenaga kerja (Wayan Rusastra, dkk. 2005)

\section{Penguasaan Lahan}

Sebagian besar pendapatan rumahtangga pedesaan umumnya berasal dari kegiatan usahatani yang membutuhkan lahan sebagai faktor produksi utama. Bagi masyarakat desa luas pemilikan lahan mencermin tingkat kesejahteraan mereka, karena hal tersebut akan menentukan besarnya pendapatan rumahtangga. Begitu pentingnya peranan lahan dalam kehidupan rumahtangga pedesaan sehingga luas pemilikan lahan seringkali diartikan identik dengan status sosial rumah tangga.

Beberapa bentuk penguasaan lahan berdasarkan Undang-Undang Pokok Agraria

(UUPA) yaitu : (i) hak milik, (ii) hak guna usaha, (iii) hak guna bangunan, (iv) hak pakai, (v) hak sewa, (vi) hak membuka tanah, (vii) hak memungut hasil hutan, (viii) hak membuka hutan, (ix) hak-hak lain yang tidak termasuk dalam hak-hak tersebut yang akan ditetapkan dengan undang-undang, serta hakhak yang bersifat sementara yaitu hak penggunaan tanah yang bukan milik sendiri. Termasuk hak yang bersifat sementara, yaitu: hak gadai, hak numpang dan hak sewa. Penguasaan lahan di perdesaan Indonesia disederhanakan kedalam kelompok milik dan bukan milik. Meskipun pengelompokan tersebut belum dapat menerangkan dengan baik eksistensi dan implikasi ekonomi dari sistem lembaga tanah adat, namun cukup baik untuk menjelaskan fenomena dinamika penguasahaan tanah dan hubungannya dengan pendapatan dan kesempatan kerja di perdesaan (Sumaryanto dan Rusastra, 2000).

$$
\text { Lahan disamping merupakan }
$$
sumberdaya, lahan juga merupakan aset kekayaan yang dimiliki oleh masyarakat yang ada di pedesaan. Dalam masa tiga tahun dinamika responden desa Patanas yang tidak memiliki lahan semakin bertambah, dari sembilan desa yang disurvay hanya dua desa berkurang responden yang tidak memiliki lahan. Atau dengan kata lain terjadi penambahan kepemilikan lahan di desa Kwala
Gunung dan Carawali, yaitu masing-masing sebanyak $1 \%$ dan $2.6 \%$ (Tabel 4). Disisi lain petani gurem atau yang memiliki lahan tidak sampai 0,25 ha semakin bertambah dengan penambahan paling tinggi terjadi di Desa Kaligondo (19.73\%) kemudian diikuti responden yang ada di desa Lidah Tanah (17.91\%) dan Desa Tugu (14\%). Pengurangan kepemilikan lahan tidak hanya terjadi pada petani gurem saja, tetapi juga dialami oleh petani yang memiliki lahan 0.25 ha sampai 1 hektar lebih. Kepemilikan $0.25-1$ ha yang paling tinggi pengurangannya terjadi di Desa Sungegeneng (43.6\%) dan kepemilikan lahan lebih dari 1 hektar paling tinggi pengurangan kepemilikannya terjadi di Desa Simpar (30.7\%).

Bagi responden yang tidak memiliki lahan, umumnya lahan yang digarap sekarang adalah lahan orang lain. Lokasi daerah Patanas yang disurvey adalah lokasi lahan sawah irigasi, sehingga lahan yang digarap adalah lahan sawah irigasi. Lahan bukan milik tersebut diperoleh dengan cara menyewa, menyakap, gadai atau mempergunakan tanah milik keluarga. Selama tiga tahun responden yang menyewa semakin bertambah banyak. Responden yang paling meningkat pesat dalam menyewa sawah terdapat di Desa Carawali dan diikuti responden yang ada di Desa Padomasan, Sungegeneng dan Desa Salu Jambu, dengan masing-masing peningkatan sebesar 20\%, 16\% dan 12\% (Tabel 5). Untuk menyakap responden paling banyak dinamikanya terjadi di Desa Sungegeneng (16\%) dan Carawali (12\%). Untuk sistem penguasaan lahan dengan sistem gadai justru mengalami penurunan paling banyak terjadi di Desa Simpar (20\%) dan Lidah Tanah (12\%). Hal yang sama juga terlihat di dua desa dalam Provinsi Sumatera Utara dimana masing-masing desa mengalami penurunan $20 \%$ memanfaatkan tanah keluarga sebagai lahan garapan.

\section{Konsumsi Rumah Tangga}

Kebutuhan rumahtangga dapat dikelompok kedalam kebutuhan pangan dan kebutuhan non pangan. Semakin sejahtera rumatangga semakin berkurang pengeluaran konsumsi pangan. Responden yang ada di Provinsi Jawa Barat, Desa Kaligondo dan Salu Jambu di Provinsi Sulawesi Selatan 
Valeriana Darwis :Dinamika keragaan kemiskinan di desa patanas .....

Tabel 4. Penguasaan Lahan Sawah Milik

\begin{tabular}{|c|c|c|c|c|c|c|c|c|c|c|c|c|}
\hline \multirow[t]{2}{*}{ Provinsi } & \multicolumn{4}{|c|}{$2007(\%)$} & \multicolumn{4}{|c|}{$2010(\%)$} & \multicolumn{4}{|c|}{ Dinamika (\%) } \\
\hline & 1 & 2 & 3 & 4 & 1 & 2 & 3 & 4 & 1 & 2 & 3 & 4 \\
\hline \multicolumn{13}{|l|}{ Jawa Barat } \\
\hline Tugu & 45.4 & 19.6 & 25.8 & 9.9 & 49.2 & 5.6 & 18.8 & 2.0 & 3.8 & -14.0 & -7.0 & -7.9 \\
\hline Simpar & 20.6 & 6.3 & 34.7 & 38.3 & 24.7 & 1.2 & 8.0 & 7.6 & 4.1 & -5.1 & -26.7 & -30.7 \\
\hline \multicolumn{13}{|l|}{ Jawa Timur } \\
\hline Kaligondo & 16.4 & 32.8 & 39.0 & 11.7 & 20.9 & 13.07 & 9.6 & 0.0 & 4.5 & - & -29.4 & -11.7 \\
\hline Sungegeneng & 27.9 & 8.2 & 49.2 & 14.8 & 40.5 & 4.4 & 5.6 & 1.6 & 12.6 & 4.4 & -43.6 & -13.2 \\
\hline Padomasan & 40.5 & 26.7 & 23.2 & 9.4 & 40.5 & 17.6 & 10.4 & 0.4 & 0.0 & -9.1 & -12.8 & -9.0 \\
\hline \multicolumn{13}{|l|}{ Sumut } \\
\hline Kwala Gunung & 43.2 & 13.7 & 36.9 & 6.2 & 42.2 & 9.6 & 6.8 & 1.2 & -1.0 & -4.1 & -30.1 & -5.0 \\
\hline Lidah Tanah & 35.6 & 32.9 & 24.0 & 7.3 & 37.1 & 14.99 & 12.9 & 2.08 & 1.5 & - & -11.1 & -5.22 \\
\hline \multicolumn{13}{|l|}{ Sulsel } \\
\hline Salu Jambu & 19.6 & 8.9 & 54.4 & 17.0 & 20.8 & 8.4 & 12.0 & 2.0 & 1.2 & -0.5 & -42.4 & -15.0 \\
\hline Carawali & 53.2 & 12.2 & 27.3 & 7.1 & 50.6 & 14.0 & 10.8 & 1.2 & -2.6 & 1.8 & -16.5 & -5.9 \\
\hline
\end{tabular}

Ket : $1=$ tidak memiliki $; 2=0,01-0,249 ; 3=0.25-1 ; 4=1$ keatas

Sumber : Irawan, B et.al. (2007) : Susilowati, H.S et.al. (2010)

Tabel 5. Penguasaan Lahan Sawah Non Milik

\begin{tabular}{|c|c|c|c|c|c|c|c|c|c|c|c|c|}
\hline \multirow[t]{2}{*}{ Provinsi } & \multicolumn{4}{|c|}{$2007(\%)$} & \multicolumn{4}{|c|}{$2010(\%)$} & \multicolumn{4}{|c|}{ Dinamika (\%) } \\
\hline & 1 & 2 & 3 & 4 & 1 & 2 & 3 & 4 & 1 & 2 & 3 & 4 \\
\hline \multicolumn{13}{|l|}{ Jawa Barat } \\
\hline Tugu & 36.0 & 0.0 & 0.0 & 4.0 & 20.0 & 0.0 & 12.0 & 0.0 & -16.0 & 0.0 & 12.0 & -4.0 \\
\hline Simpar & 12.0 & 8.0 & 32.0 & 0.0 & 4.0 & 8.0 & 12.0 & 0.0 & -8.0 & 0.0 & -20.0 & 0.0 \\
\hline \multicolumn{13}{|l|}{ Jawa Timur } \\
\hline Kaligondo & 8.0 & 4.0 & 4.0 & 4.0 & 16.0 & 0.0 & 0.0 & 0.0 & 8.0 & -4.0 & -4.0 & -4.0 \\
\hline Sungegeneng & 24.0 & 0.0 & 0.0 & 8.0 & 36.0 & 16.0 & 8.0 & 0.0 & 12.0 & 16.0 & 8.0 & -8.0 \\
\hline Padomasan & 0.0 & 12.0 & 0.0 & 4.0 & 16.0 & 8.0 & 0.0 & 4.0 & 16.0 & -4.0 & 0.0 & 0.0 \\
\hline \multicolumn{13}{|l|}{ Sumut } \\
\hline Kwala Gunung & 56.0 & 0.0 & 12.0 & 20.0 & 56.0 & 0.0 & 0.8 & 0.0 & 0.0 & 0.0 & -4.0 & -20.0 \\
\hline Lidah Tanah & 16.0 & 4.0 & 12.0 & 20.0 & 4.0 & 0.0 & 0.0 & 0.0 & -12.0 & -4.0 & -12.0 & -20.0 \\
\hline \multicolumn{13}{|l|}{ Sulsel } \\
\hline Salu Jambu & 0.0 & 16.0 & 8.0 & 12.0 & 12.0 & 24.0 & 0.0 & 2.5 & 12.0 & 8.0 & -8.0 & 0.0 \\
\hline Carawali & 0.0 & 68.0 & 0.0 & 20.0 & 20.0 & 80.0 & 0.0 & 0.0 & 20.0 & 12.0 & 0.0 & 0.0 \\
\hline
\end{tabular}

Ket : $1=$ Menyewa ; $2=$ Menyakap ; $3=$ Gadai ; $4=$ Tanah Keluarga

Sumber : Irawan, B et.al. (2007) : Susilowati, H.S et.al. (2010)

pengeluaran untuk kebutuhan pangannya pada tahun 2010 mengalami kenaikan dibandingkan tahun 2007. Desa Salu Jambu mengalami kenaikan yang paling tinggi yaitu $12.4 \%$, sedangan responden di Desa Kaligondo kenaikan pengeluarannya paling rendah yaitu $0.28 \%$. Desa yang paling tinggi mengalami penurunan pengeluaran konsumsi untuk pangan adalah desa Padomasan, sebaliknya desa Lidah Tanah yang paling sedikit mengalami penurunan pengeluaran konsumsi pangan, yaitu dengan masing-masing pengeluaran $-9.21 \%$ dan $-1.02 \%$ (Tabel 6 ).
Total pengeluaran perbulan merupakan salah satu indikator kemiskinan. Pengertian kemiskinan antara satu negara dengan negara lain juga berbeda. Pengertian kemiskinan di Indonesia dibuat oleh BPS. Lembaga tersebut mendefinisikan kemiskinan dengan membuat kriteria besarannya pengeluaran per orang per hari sebagai bahan acuan. Dalam konteks itu, pengangguran dan rendahnya penghasilan menjadi pertimbangan untuk penentuan kriteria tersebut.

Kriteria statistik BPS tersebut adalah : 
1. Tidak miskin, mereka yang pengeluaran per orang per bulan lebih dari Rp 350.610.

2. Hampir Tidak Miskin, dengan pengeluaran per bulan per kepala antara Rp 280.488.s/d. - Rp 350.610.- atau sekitar antara Rp $9.350 \mathrm{~s} / \mathrm{d}$. Rp11.687.- per orang per hari. Jumlahnya mencapai 27,12 juta jiwa.

3. Hampir Miskin, dengan pengeluaran per bulan per kepala antara Rp 233.740.- s/d Rp 280.488.- atau sekitar antara $\mathrm{Rp} 7.780$.s/d Rp 9.350.- per orang per hari. Jumlahnya mencapai 30,02 juta.

4. Miskin, dengan pengeluaran per orang perbulan per kepala Rp 233.740.-kebawah atau sekitar Rp 7.780.- kebawah per orang per hari. Jumlahnya mencapai 31 juta.

5. Sangat Miskin (kronis), tidak ada kriteria berapa pengeluaran per orang per hari. Tidak diketahui dengan pasti berapa jumlah pastinya. Namun, diperkirakan mencapai sekitar 15 juta.

Berdasarkan indikator BPS pada tahun 2013 pengeluaran rata-rata untuk keluarga miskin per orang perbulan sebesar Rp. 233.740, kalau rata-rata satu keluarga 2 orang anak maka pengeluaran perbulannya menjadi Rp. 934.960. Sementara pengeluaran keluarga miskin pada tahun 2007 perorang perbulan sebesar Rp. 211.726 atau Rp. 846.904 untuk satu keluarga 4 orang jiwa. Berdasarkan nominal pengeluaran tersebut seluruh desa dilokasi penelitian Patanas termasuk desa miskin.
Kalau dilihat dinamika pengeluaran dari tahun 2007 ke 2010, seluruh responden di desa Patanas mengalami kenaikan pengeluaran perbulan dengan Desa Carawali yang mengalami kenaikan paling tinggi (Rp. 253.100) dan Desa Lidah Tanah yang mengalami kenaikan pengeluaran yang paling rendah (Rp. 9.380).

Jenis pengeluaran pangan yang paling banyak yang terjadi di empat provinsi yang disurvey adalah pembelian sumber karbohidrat. Hal ini dianggap wajar, karena kebutuhan karhohidarat merupakan kebutuhan pokok yang dikonsumsi relatif lebih banyak dibandingkan jenis pengeluaran pangan lainnya. Tetapi dalam perkembangannya kebutuhan untuk membeli nasi mengalami dinamika penurunan 5 sampai 10 persen, hanya provinsi Sumatera Utara saja yang mengalami kenaikan responden membeli kebutuhan karbohidrat (Tabel 7). Kebutuhan kecukupan gizi yang diperoleh dari konsumsi pangan hewani, sayuran dan buah-buahan, umumnya mengalami pertumbuhan yang positif. Hal ini bisa diartikan adanya kesadaran keluarga responden untuk menjadikan anggota keluarga lebih sehat. Hal ini juga diperkuat dengan mulai berkurangnya responden membeli (i) makanan atau minuman jadi di toko atau warung makanan, (ii) mengurangi pembelian tembakau dan sirih. Meskipun tidak banyak masing-masing pengurangannya antara 0.5 persen sampai 2.5 persen untuk membeli makanan dan minuman jadi dan antara $0.7-4$ persen dalam membeli tembakau dan sirih.

Tabel 6. Persentase Pengeluaran Pangan dan Pengeluaran Total

\begin{tabular}{lcccccr}
\hline Provinsi & \multicolumn{3}{c}{ Pengeluaran Pangan (\%) } & \multicolumn{3}{c}{ Pengeluaran Pangan (Rp/bulan) } \\
\cline { 2 - 7 } & 2007 & 2010 & Dinamika & 2007 & 2010 & Dinamika \\
\hline Jawa Barat & & & & & & \\
Tugu & 49.7 & 54.00 & 4.3 & 332.460 & 412.010 & 79.550 \\
Simpar & 49.4 & 53.92 & 4.52 & 360.690 & 491.320 & 130.630 \\
Jawa Timur & & & & & & \\
Kaligondo & 48.3 & 48.58 & 0.28 & 210.700 & 414.410 & 203.710 \\
Sungegeneng & 58.5 & 50.52 & -7.98 & 225.570 & 401.330 & 175.760 \\
Padomasan & 60.5 & 51.29 & -9.21 & 241.960 & 384.720 & 142.760 \\
Sumut & & & & & & \\
Kwala Gunung & 57.3 & 56.28 & -1.02 & 234.540 & 424.200 & 189.660 \\
Lidah Tanah & 59.2 & 58.54 & -.066 & 393.630 & 403.010 & 9.380 \\
Sulsel & & & & & & \\
Salu Jambu & 48.6 & 61.00 & 12.4 & 203.990 & 332.580 & 128.590 \\
Carawali & 55.2 & 52.26 & -2.94 & 282.610 & 535.710 & 253.100 \\
\hline Sal :
\end{tabular}

Sumber : Irawan, B et.al. (2007) : Susilowati, H.S et.al. (2010) 
Valeriana Darwis :Dinamika keragaan kemiskinan di desa patanas .....

Tabel 7. Pangsa Pengeluaran Pangan dan Non Pangan

\begin{tabular}{|c|c|c|c|c|c|c|c|c|c|c|c|c|}
\hline \multirow[t]{2}{*}{ Pengeluaran } & \multicolumn{3}{|c|}{ Jabar } & \multicolumn{3}{|c|}{ Jatim } & \multicolumn{3}{|c|}{ Sumut } & \multicolumn{3}{|c|}{ Sulsel } \\
\hline & 2007 & 2010 & $\mathrm{D}$ & 2007 & 2010 & $\mathrm{D}$ & 2007 & 2010 & $\mathrm{D}$ & 2007 & 2010 & $\mathrm{D}$ \\
\hline \multicolumn{13}{|l|}{ Pangan } \\
\hline Sumber Karbohidrat & 26.4 & 22.2 & -4.2 & 32.0 & 22.5 & -9.5 & 23.6 & 27.1 & 3.5 & 32.2 & 23.3 & -8.9 \\
\hline Pangan Hewani & 14.4 & 19.0 & 4.6 & 16.0 & 19.7 & 3.7 & 23.0 & 22.5 & -0.5 & 18.6 & 24.1 & 5.5 \\
\hline Sayuran & 5.0 & 15.1 & 10.1 & 5.2 & 11.1 & 5.9 & 4.1 & 12.3 & 8.2 & 3.2 & 13.5 & 10.3 \\
\hline Kacang2an & 9.7 & 4.8 & -4.9 & 8.1 & 5.1 & -3.0 & 10.4 & 3.0 & -7.4 & 10.9 & 3.2 & -7.7 \\
\hline Buahan & 4.1 & 4.0 & -0.1 & 2.8 & 7.6 & 4.8 & 4.1 & 7.1 & 3.0 & 4.0 & 4.4 & 0.4 \\
\hline Minyak\&lemak & 3.9 & 4.9 & 1.0 & 5.9 & 6.2 & 0.3 & 4.0 & 4.5 & 0.5 & 3.6 & 4.1 & 0.5 \\
\hline Bahan Minuman & 5.6 & 7.2 & 1.6 & 6.1 & 7.1 & 1 & 8.2 & 6.4 & -1.8 & 6.8 & 7.5 & 0.7 \\
\hline Makanan\&min jadi & 6.7 & 4.8 & -1.9 & 2.7 & 5.4 & 2.7 & 6.2 & 3.9 & -2.3 & 4.6 & 4.2 & -0.4 \\
\hline Tembakau\&sirih & 14.2 & 10.4 & -3.8 & 8.1 & 7.4 & -0.7 & 12.1 & 9.3 & -2.8 & 10.1 & 8.1 & -2.0 \\
\hline lainnya & 6.9 & 7.6 & 0.7 & 13.2 & 7.9 & -5.3 & 4.6 & 4.0 & 0.6 & 6.3 & 7.6 & 1.3 \\
\hline \multicolumn{13}{|l|}{ Non Pangan } \\
\hline Bahan Bakar & 36.9 & 30.2 & -6.7 & 33.8 & 18.8 & -15.0 & 28.7 & 18.5 & -10.2 & 32.0 & 24.0 & -8.0 \\
\hline Komunikasi & 4.5 & 4.4 & -0.1 & 4.5 & 5.3 & 0.8 & 4.1 & 2.2 & -1.9 & 4.9 & 4.2 & -0.7 \\
\hline Pendidikan & 30.5 & 24.8 & -5.7 & 31.5 & 20.2 & -11.3 & 24.0 & 16.6 & -7.4 & 28.6 & 23.4 & -5.2 \\
\hline Kesehatan & 13.0 & 13.3 & 0.3 & 15.9 & 15.4 & -0.5 & 23.0 & 33.0 & 10.0 & 17.7 & 17.6 & -0.1 \\
\hline Sandang & 8.8 & 10.4 & 1.6 & 8.7 & 5.5 & -3.2 & 12.9 & 6.8 & -6.1 & 9.9 & 7.4 & -2.5 \\
\hline Lainnya & 6.3 & 16.9 & 10.6 & 7.6 & 34.7 & 27.1 & 7.5 & 22.9 & 15.4 & 7.4 & 23.3 & 15.9 \\
\hline
\end{tabular}

Sumber : Irawan, B et.al. (2007) : Susilowati, H.S et.al. (2010)

Sementara pengeluaran untuk non pangan paling banyak terjadi di pembelian bahan bakar dan biaya pendidikan. Tetapi dalam berjalannya waktu biaya untuk kebutuhan bahan bakar dan pendidikan mengalami penurunan, sampai 15 persen di Provinsi Jawa Timur dan terendah di provinsi Jawa Barat (6.7\%). Biaya pendidikan juga mengalami penurunan pada tahun 2010 dibandingkan tahun 2007 dengan provinsi Jawa Timur yang paling tinggi $(11.3 \%)$ dan provinsi Sulawesi Selatan yang paling rendah penurunannya $(5.2 \%)$. Penurunan biaya pendidikan ini merupakan dampak positif dari kebijakan pemeritah yang menggratiskan pendidikan sampai lulus SMP program wajib belajar 9 tahun.

\section{Upaya Mengatasi Kemiskinan}

Bappenas (2004) mendefenisikan kemiskinan sebagai kondisi dimana seseorang atau sekelompok orang, laki-laki dan perempuan tidak mampu memenuhi hak-hak dasarnya untuk mempertahankan dan mengembangkan kehidupan yang bermartabat. Hak-hak dasar masyarakat desa antara lain terpenuhinya kebutuhan pangan, kesehatan, pendidikan, pekerjaan, perumahan, air bersih, pertanahan, sumberdaya alam dan lingkungan hidup, rasa aman dari perilaku atau ancaman tindak kekerasan dan hak untuk berpartisipasi dalam kehidupan sosil politik, baik perempuan maupun laki-laki.

Ada empat eleman utama yang menjadi kebutuhan dasar/pokok keluarga, yaitu : kebutuhan pangan, sandang, kesehatan dan pendidikan. Apabila empat elemen tersebut tidak terpenuhi maka keluarga tersebut termasuk kelompok keluarga miskin. Bappenas (2004) telah membuat indikator untuk kebutuhan dasar tersebut : (i) terbatasnya kebutuhan pangan dilihat dari stok pangan yang terbatas, rendahnya asupan kalori penduduk miskin dan buruknya status gizi bayi, anak balita dan ibu. (ii) terbatasnya akses dan rendahnya mutu layanan kesehatan disebabkan oleh kesulitan mendapatkan layanan kesehatan dasar, rendahnya mutu layanan kesehatan dasar, kurangnya pemahaman terhadap perilaku hidup sehat, dan kurangnya layanan kesehatan reproduksi, jarak fasilitas kesehatan yang jauh dan biaya perawatan dan pengobatan yang mahal. (iii) terbatasnya akses dan rendahnya mutu layanan pendidikan disebabkan oleh kesenjangan biaya pendidikan, fasilitas pendidikan yang terbatas, biaya pendidikan yang mahal, kesempatan memperoleh pendidikan yang terbatas, tingginya beban biaya pendidikan baik biaya langsung maupun tidak langsung.

Indikator kemiskinan di lokasi Patanas dibangun melalui persepsi responden. Keluarga disebut miskin apabila frekuensi makannya 
kurang dari 2 kali dalam sehari, konsumsi pangan pokok setara beras kurang dari 240 $\mathrm{kg} / \mathrm{kap} / \mathrm{thn}$, konsumsi pangan hewani kurang dari 1 kali/minggu. Kemiskinan sandang indikatornya membeli sandang satu kali dalam satu tahun dan pakaian yang dipergunakan tidak berbeda disetiap kegiatan. Indikator pendidikan terlihat pada anggota keluarga yang berumur 10-60 tahun tidak bisa baca tulis huruf latin dan ada anggota keluarga yang berumur 5-15 tahun tidak bersekolah. Indikator kesehatan terlihat pada keluarga yang sakit tetapi tidak berobat ke sarana kesehatan.

\section{Kebutuhan Pangan}

Tingkat kecukupan pangan pokok yang dipersepsikan sebagai indikator kemiskinan adalah frekuensi makan. Dalam suatu komunitas adakalanya tidak terdapat perbedaan menyolok dalam hal pemenuhan pangan, karena pola konsumsi anggota responden relatif sama karena faktor budaya maupun alam. Seperti di Luwu manurut alam masih cukup menyediakan bahan pangan secara melimpah dan masih dapat diakses oleh semua pihak asalkan mau berusaha. Pada kasus di Kabupaten Sragen Banyuwangi dan Jember pangan tidak bisa dijadikan indikator karena pola pangan dan bahan pangan yang dikonsumsi relatif tidak berbeda antar rumahtangga, yaiu berupa bahan pangan pokok ditambah dengan aneka sayuran yang dihasilkan dari kebun sendiri atau meminta dari tetangga. Namun demikian menurut mereka dari segi kualitas mungkin saja terdapat perbedaan namun tidak dari segi frekuensi.

Untuk mengatasi kesulitan pangan ada beberapa startegi yang dijalankan oleh responden patanas yang dikelompokkan kedalam strategi mengurangi frekuensi makan, berhutang ke warung, menjual perabot, meminjam uang dan menggadaikan tanaman tahunan. Dari beberapa strategi tersebut dinamika strategi memenuhi kekurangan pangan diperoleh dengan cara meminjam uang lebih dominan dilaksanakan oleh keluarga responden baik yang ada di Pulau Jawa maupun di luar Pulau Jawa (Tabel 8). Diurutan selanjutnya strategi dalam memenuhi kebutuhan pangan dengan cara mengurangi frekuensi makan 23.3\% di Pulau Jawa dan menjual perabot rumah tangga di luar Pulau Jawa $(16.2 \%)$.

\section{Kebutuhan Sandang}

Pakaian dapat digunakan untuk menjadi indikator kemiskinan, walaupun saat ini banyak pilihan untuk mendapatkan pakaian sesuai kemampuan dengan tampilan yang sepintas lalu tidak banyak berbeda. Bagi masyarakat pedesaan umumnya penampilan tidak dianggap prioritas dibandingkan dengan pemenuhan kebutuhan yang lain. Namun kondisi berbeda dijumpai pada masyarakat Subang. Tampilan dinilai sangat penting dan biasanya orang kaya akan membeli bahan pakaian yang relatif mahal. Terlebih lagi yang membedakan menurut mereka adalah aksesorisnya, berupa perhiasan emas yang pemiliknya akan berbanding lurus dengan tingkat kekayaan pemiliknya.

Strategi yang dipergunakan oleh responden dalam mengatasi kebutuhan pangan antara lain hanya membeli pakaian untuk seragam sekolah, membeli pakaian bekas, mengurangi jumlah atau menurunkan kualitas. Dinamika strategi mengatasi pangan dengan cara mengurangi jumlah dan menurunkan kualitas mengalami peningkatan di keluarga responden di pulau Jawa dan sebaliknya membeli pakaian seragam sekolah mengalami penurunan. Berkurangnya keluarga responden dalam memenuhi kebutuhan pakaian seragam sekolah salah satu penyebabnya adalah adanya bantuan bansos pendidikan.

Hal yang berbeda terjadi di keluarga responden yang ada di luar Pulau Jawa dimana strategi mengurangi jumlah dan kualitas pakaian mengalami penurunan yang sangat signifikan atau mengalami penurunan sebesar $59 \%$ dan $40 \%$. Sebaliknya membeli pakaianan hanya untuk kebutuhan seragam sekolah mengalami dinamika positif $2 \%$ dan membeli pakaian bekas meningkat $3 \%$.

\section{Kebutuhan Kesehatan}

Sejak adanya askeskin, akses masyarakat terhadap pelayanan kesehatan dasar relatif lebih meningkat. Namun rersponden juga menyatakan bahwa akan lebih mudah bagi orang kaya untuk memilih dan mengakses pelayanan kesehatan yang lebih bagus kualitasnya, dibandingkan dengan rumah tangga miskin.

Untuk mengatasi kesulitan untuk mendapatkan kesehatan, responden di pulau Jawa mengatasinya dengan cara meminjam uang dan mendaftarkan diri sebagai peserta askeskin. 
Valeriana Darwis :Dinamika keragaan kemiskinan di desa patanas .....

Tabel 8. Strategi Mengatasi Kemiskinan

\begin{tabular}{|c|c|c|c|c|c|c|}
\hline \multirow[t]{2}{*}{ Kesulitan dalam } & \multicolumn{3}{|c|}{ Jawa (\%) } & \multicolumn{3}{|c|}{ Luar Jawa (\%) } \\
\hline & 2007 & 2010 & Dinamika & 2007 & 2010 & Dinamika \\
\hline \multicolumn{7}{|l|}{ Pangan } \\
\hline Frekuensi makan dikurangi & 12.0 & 35.3 & 23.3 & 27.0 & 9.1 & -17.9 \\
\hline Berhutang ke warung & 23.2 & 23.5 & 0.3 & 16.0 & 18.2 & 2.2 \\
\hline Menjual perabot rumah tangga & 5.3 & - & -5.3 & 2.0 & 18.2 & 16.2 \\
\hline Meminjam uang & 37.0 & 64.7 & 27.7 & 31.0 & 72.7 & 41.7 \\
\hline Menggadaikan tanaman tahunan & 5.3 & - & -5.3 & 2.0 & 9.1 & 7.1 \\
\hline \multicolumn{7}{|l|}{ Sandang } \\
\hline $\begin{array}{l}\text { Membeli pakaian seragam } \\
\text { sekolah }\end{array}$ & 29.6 & 12.5 & -17.1 & 48.0 & 50.0 & 2.0 \\
\hline Membeli pakaian bekas & 21.3 & - & -21.3 & 27.0 & 30.0 & 3.0 \\
\hline Mengurangi jumlah & 58.0 & 62.5 & 4.5 & 79.0 & 20.0 & -59.0 \\
\hline Menurunan kualitas & 40.0 & 50.0 & 10.0 & 70.0 & 30.0 & -40.0 \\
\hline \multicolumn{7}{|l|}{ Kesehatan } \\
\hline Tidak Berobat & 6.0 & 7.1 & 1.1 & 12.0 & 11.1 & -0.9 \\
\hline $\begin{array}{l}\text { Mendaftar sebagai peserta } \\
\text { askeskin }\end{array}$ & 25.6 & 42.9 & 17.3 & 34.0 & 66.7 & 32.7 \\
\hline Meminjam uang & 39.2 & 57.1 & 17.9 & 49.0 & 11.1 & -37.9 \\
\hline Menjual ternak & 27.0 & 14.3 & -12.7 & 27.0 & - & -27.0 \\
\hline \multicolumn{7}{|l|}{ Pendidikan } \\
\hline $\begin{array}{l}\text { Mengupayakan mendapat } \\
\text { beasiswa }\end{array}$ & 12.0 & 7.7 & -4.3 & 30.0 & 20.0 & -10.0 \\
\hline Drop out & 16.0 & 46.2 & 30.2 & 22.0 & - & -22.0 \\
\hline Meminjam uang & 21.6 & 23.1 & 1.5 & 40.0 & 80.0 & 40.0 \\
\hline Menjual ternak & 19.2 & 15.4 & -3.8 & 35.0 & - & -35.0 \\
\hline
\end{tabular}

Sumber : Irawan, B et.al. (2007) : Susilowati, H.S et.al. (2010)

Strategi ini mengalami peningkatan $17,9 \%$ dengan cara meminjam uang dan meningkat $17,2 \%$ dengan cara mendaftar sebagai peserta askeskin. Hal yang sama juga terjadi di responden di luar pulau Jawa, dimana peningkatan menjadi peserta askeskin bertambah $32,7 \%$. Sebaliknya meminjam uang dan menjual ternak mengalami penurunan $37,9 \%$ dan $27 \%$.

\section{Kebutuhan Pendidikan}

Dengan adanya BOS minimal masyarakat desa sudah dapat mengecap pendidikan sampai tingkat sekolah dasar, sehingga pada tingkat ini belum terdapat perbedaan antara keluarga miskin atau tidak. Namun pada tingkat selanjutnya bagi masyarakat yang apresiasinya terhadap pendidikan sudah lebih baik, maka perbedaan akan semakin terlihat.

Untuk mengatasi masalah pendidikan bagi keluarga yang sudah tidak mampu khususnya di pulau Jawa lebih mimilih tidak usah melanjutkan (drop out) dan strategi ini mengalami peningkatan dibanding tahun 2007 (30.2\%). Strategi yang mengalami peningkatan di responden luar pulau Jawa (40\%) adalah meminjam uang apabila ada masalah di bidang pendidikan. Strategi lainnya seperti mengupayakan mendapatkan beasiswa, tidak melanjutkan sekolah dan menjual ternak mengalami dinamika negatif.

\section{KESIMPULAN}

Keragaan kemiskinan direpresentasikan dari kesempatan kerja, sumber pendapatan, penguasaan lahan, konsumsi rumah tangga 
pangan dan non pangan. Dinamika keragaan kemiskinan tersebut antara tahun 2007 dan 2010 mengalami pertumbuhan yang negatif, hal ini terlihat dari : (i) kesempatan kerja berkurang dan pengangguran bertambah, (ii) sumber pendapatan umumnya dari pertanian, tetapi sumber pendapatan justru bertambah di non pertanian, (iii) kepemilikan lahan antara $0,25-$ 1 ha mengalami penurunan dan sebaliknya yang menyewa lahan garapan semakin bertambah, (iv) pengeluaran untuk kebutuhan pangan bertambah terutama untuk memenuhi kebutuhan karbohidrat dan sumber hewani.

Banyak upaya yang dilakukan untuk mengatasi masalah pangan, upaya yang sering dilakukan responden dengan cara meminjam uang. Cara meminjam uang ini mengalami peningatan pada tahun 2010 dibandingkan tahun 2007. Upaya kesulitan memenuhi sandang dinamika positifnya paling tinggi dengan cara mengurangi jumlah pembelian. Upaya kesulitan memenuhi kesahatan dinamika positifnya yang paling tinggi ditempuh dengan cara menjadi peserta askeskin (asuransi kesehatan miskin). Upaya mengatasi pendidikan dinamika yang paling tinggi dengan cara meminjam uang atau tidak melanjutkan pendidikan.

\section{SARAN}

Program pemerintah sudah banyak dalam mengatasi persoalan kemiskinan dan program tersebut sudah dirasakan manfaatnya oleh masyarakat sebagai salah satu upaya dalam mengatasi masalah pangan, sandang, kesehatan dan pendidikan. Kedepannya untuk program kesehatan seperti bantuan operasional kesehatan untuk puskesmas, jaminan kesehatan masyarakat miskin serta pembangunan rumah sakit ; program penyediaan papan dalam program keluarga harapan ; program pangan dalam bentuk bantuan beras miskin perlu diteruskan dan ditingkatkan. Untuk peningkatan pendapatan petani padi dapat ditempuh dengan cara meningkatkan adopsi teknologi budidaya berupa pemakaian benih unggul, pemakaian jenis dan dosis pupuk yang efektif dan efisien.

\section{DAFTAR PUSTAKA}

BPS. 2014. Jumlah Penduduk Miskin Maret 2013 Mencapai 28,07 Juta Orang. http://www.bps.go.id/?news=1023
Darwis.V dan A.H. Rozany (2001). Pengentasan Kemiskinan : Upaya Yang Telah Dilakukan dan Rencana Waktu Mendatang. Forum Agro Ekonomi. Hal 55-67. Pusat Penelitian dan Pengembangan Sosial Ekonomi Pertanian.

Harniati, 2007 dalam http://www.suaramerdeka.com/cybernew s/harian/0706/21/nas $15 . h t m$

Irawan,B., P. Simatupang, R. Kustiri, Sugiarto, Supadi, Yulia,F.S, M. Iqbal, M. Ariani, V. Darwis, R. Elizabet, Sunarsih, C.Muslim, T.B. Purwantini dan T. Nurasa. 2007. Panel Petani Nasional (Patanas) Analisis Indikator Pembangunan Pertanian dan Perdesaan. Laporan Hasil Penelitian. Pusat Analisis dan Kebijakan Pertanian. Bogor.

Iksan, M. 1998. The Disaggregation of Indonesia Poverty : Policy and Analysis. An Unpublished PhD Thesis. University of Illinois at Urbana-Champaign. IL. USA

Kasryno,F and A. Suryana. 1992. Long Trem Planning For Agricultural Development Related to Poverty Alleviation in Rural Areas. Dalam Pasandaran, E. Et al (Eds) Poverty Alleviation With Sustainable Agricultural and Rural Development in Indonesia. Proceedings of National Seminar and Workshop. Pp 60-70

Kustiari,R., P.U. Hadi, Sugiarto, A. Purwoto, Supadi, M. Ariani, Sunarsih, Y.F. Sinuraya, D. Hidayat, M. Maulana, T.B. Purwantini, B. Winarso dan Waluyo. 2008. PATANAS Analisis Indikator Pembangunan Pertanian dan Pedesaan. Laporan Hasil Penelitian. Pusat Analisis dan Kebijakan Pertanian.

Made. B. 2013. Akhiri Kemiskinan. http://www.setkab.go.id/

Mason. A. 1996. Targeting The Poor in Rural Java. IDS Bulletin vol. 27 (1) : 67-82

Rusastra.I.W, K. M. Noekman, Supriyati, E. Suryani, M. Suryadi dan R. Elizabeth. 2005. Analisis

Ekonomi 
Valeriana Darwis :Dinamika keragaan kemiskinan di desa patanas .....

Ketenagakerjaan Sektor Pertanian dan Pedesaan di Indonesia. Laporan Hasil Penelitian. Pusat Penelitian dan Pengembangan Sosial Ekonomi Pertanian. Bogor.

Suara Pembaharuan. Mengentaskan Kemiskinan Bukanlah Perbuatan Amal, Tapi Merupakan Tindakan Keadilan. Selasa, 26 Maret 2013)

Sumaryanto dan I.W.Rusastra. 2000. Struktur Penguasaan Tanah dan Hubungannya Dengan Kesejahteraan Petani. Prospektif Pembangunan Pertanian dan Pedesaan Dala Era otonomi Daerah.
Pusat Penelitian Sosial Ekonomi Pertanian, Bogor.

Suroto. 2014. Kemiskinan dan Ketergantungan. Kompas. 8 April 2014. Hal 7

Susilowati, H.S., B. Hutabarat, M. Rachmat, A. Purwoto, Sugiarto, Supriyati, Supadi, A. Zakaria, B. Winarso, H. Supriyadi, T.B. Purwantini, R.Elizabeth, D. Hidayat, T. Nurasa, C. Muslim, M. Maulana, M.Iqbal dan R. Aldilah. 2010. Indikator Pembangunan Pertanian dan Pedesaan: Karakteristik Sosial Ekonomi Petani dan Usahatani Padi. Laporan Hasil Penelitian. Pusat Analisis dan Kebijakan Pertanian. Bogor. 